\title{
Performance evaluation of horizontal and vertical flow constructed wetlands as tertiary treatment option for secondary effluents
}

\author{
Arun Kumar Thalla ${ }^{1}$ (I) C. P. Devatha ${ }^{1} \cdot$ K. Anagh ${ }^{1} \cdot$ Elsa Sony $^{1}$
}

Received: 17 January 2019 / Accepted: 24 June 2019 / Published online: 24 July 2019

(c) The Author(s) 2019

\begin{abstract}
Constructed wetlands (CWs) are simple low-cost wastewater treatment units that use natural process to improve the effluent water quality and make it possible for its reuse. In the present study, a comparison is made between horizontal subsurface flow (HSSF-CW) and vertical flow (VFCW) constructed wetland in effectively post-treating the effluents from the secondary biological treatment system. Locally available plants, viz. Pennisetum pedicellatum and Cyperus rotundus, which are abundantly available in the Western Ghats, were used in the wetland. A pilot-scale study was undertaken in National Institute of Technology, Karnataka Campus. The experiments were conducted at two hydraulic retention times, i.e., $12 \mathrm{~h}$ and $24 \mathrm{~h}$. The experimental study was carried out in February 2018 to May 2018. Concentration-based average removal efficiencies for HSSF-CW and VFCW were BOD, 77\% and 83\%; COD, 60\% and 65\%; $\mathrm{NH}_{4}{ }^{+}-\mathrm{N}, 67 \%$ and $84.47 \%$; $\mathrm{NO}_{3}-\mathrm{N}, 69 \%$ and $66.75 \%$; and $\mathrm{PO}_{4}-\mathrm{P}, 85 \%$ and $90 \%$, respectively. VFCW showed a better overall removal efficiency than HSSF-CW by $7.14 \%$. Thus, constructed wetland can be considered as a sustainable alternative to the tertiary conventional treatment of domestic wastewater, thus making it possible for reuse.
\end{abstract}

Keywords Horizontal subsurface $\cdot$ Vertical flow $\cdot$ Wetlands $\cdot$ Recycle $\cdot$ Wastewater

\section{Introduction}

India is facing serious droughts for the last two decades in many parts of the country, as there is a significant reduction in agricultural production due to the shortage of rains and excessive withdrawal of groundwater for non-agricultural purposes, thus leading to agricultural and economic impacts. One best way to handle this situation is to effectively treat the domestic wastewater and effectively reuse. The conventional sewage treatment has frequently been unsuccessful in developing countries due to the complex operating procedures, costly maintenance actions, production of sludge and high energy consumption (Arts 2012). In recent times, there has been a growing interest in using constructed wetlands (CWs) for the treatment of polluted waters because of its low greenhouse effects, low operational and maintenance costs and energy efficiency. CWs are engineered passive systems with a media on which suitable aquatic plants are grown

Arun Kumar Thalla

thallpce@gmail.com

1 Department of Civil Engineering, NITK Surathkal, Mangalore, Karnataka 575025, India
(Kadlec and Wallace 2008). Constructed wetland utilization can provide sustainable wastewater treatment because they rely on natural processes and are less expensive to build, operate and maintain when compared with conventional sewage treatment systems. The filtered water is suitable for reuse and reaped plants can have commercial value. All these are aids for the use of this wastewater treatment technology in developing countries facing socioeconomic challenges (Wu and Sansalone 2013).

CWs are subdivided into two types based on water flow: (1) surface flow (SF) or free water surface flow wetlands, where wastewater is flowing horizontally over the wetland substrate; (2) subsurface flow (SSF), in which the wastewater flows horizontally or vertically through the highly permeable substrate (gravel, rock or soil). These systems treat different types of wastewater like domestic wastewater (Zurita et al. 2009; Wu and Sansalone 2013), acid mine drainage (Nyquist and Greger 2009), urban sewage (Prochaska and Zouboulis 2006; Prochaska et al. 2007; Zhao et al. 2010), agricultural wastewaters, landfill leachate (Yalcuk and Ugurlu 2009), urban storm water (States 2000) and industrial wastewater (Vymazal 2014). A pre-treatment with conventional processes is usually desirable before discharge into a wetland 
because of the potential solids or oxygen demand overload that create nuisance conditions within a wetland receiving raw or inadequately treated wastewaters (Kadlec and Wallace 2008).

Pilot-scale studies were conducted in perfectly designed horizontal subsurface flow constructed wetland (HSSF$\mathrm{CW}$ ) and vertical flow constructed wetland (VFCW). The pilot-scale model was developed to apply the approach of constructed wetland system under the local circumstances of National Institute of Technology, Karnataka (NITK), and similar regions as a post-treatment option, where we can reclaim the wastewater and use it for alternate purposes. The main concept of this project is to implement a compliant onsite natural treatment system. The materials used for the project are all locally available and easily accessed. This makes it adaptable to similar regions, which makes cost-effective reclamation of wastewater and is adaptive for households for reclaiming the left out water.

\section{Materials and methods}

\section{Study area}

The study area is located at the National Institute of Technology, Surathkal, situated in Mangalore in western Kannada region of Karnataka, India $\left(13^{\circ} 00^{\prime} 43.8^{\prime \prime} \mathrm{N} 74^{\circ} 47^{\prime} 54.2^{\prime \prime} \mathrm{E}\right)$. Being situated in a semiarid region and near the coastal zone, the temperature in the study area remains more or less constant throughout the year. The annual average rainfall and

Table 1 Mean values of temperature

\begin{tabular}{llllll}
\hline Parameter & \multicolumn{3}{l}{ Month } & & \\
\cline { 2 - 6 } & Jan & Feb & March & April & May \\
\hline Temperature $\left({ }^{\circ} \mathrm{C}\right)$ & 33 & 33 & 34 & 35 & 32 \\
\hline
\end{tabular}

annual average temperature are $3783 \mathrm{~mm}$ and $27^{\circ} \mathrm{C}$, respectively. Table 1 provides the mean values of the temperature recorded during the experimental period.

\section{Existing STP}

NITK treatment plant is one of the treatment plants inside the campus, which receives water from girls hostel and staff quarters of NITK. The girls hostel is having occupancy of about 1000, and that of the staff quarters is about 1300 . The pilot-scale study is done for the effluent taken out from the existing treatment plant. The layout of the existing treatment plant and the proposed area for the pilot plant is shown in Fig. 1a, and the secondary treatment is done by wellaccepted activated sludge process. It receives raw wastewater with an average chemical oxygen demand (COD) of $500 \mathrm{mg} / \mathrm{l}$ and biological oxygen demand (BOD) of $300 \mathrm{mg} / \mathrm{l}$ and an average effluent concentration of $250 \mathrm{mg} / \mathrm{l}$ for COD and $100 \mathrm{mg} / \mathrm{l}$ for $\mathrm{BOD}_{5}$, which neither meets the discharge standards to dispose it to streams nor can be reused. So it is proposed to have a post-treatment to the effluents of the secondary treatment unit so as to bring it to reusable levels. The layout of the proposed wetlands pilot plant is shown in Fig. $1 b$.

\section{Design of pilot-scale model}

\section{Design of pilot-scale HSSF-CW}

The pilot-scale wetland system is of $1.45 \mathrm{~m}^{2}$ area. The sizing of the wetland was in accordance with Wallace and Knight (2006) and the design considerations based on the total area required to remove the pollutant. The areal loading rate for $\mathrm{BOD}_{5}$ is fixed as $22 \mathrm{~kg} / \mathrm{ha}$ day (USEPA 2000). The tank was $1.32 \mathrm{~m}$ long and $1.1 \mathrm{~m}$ wide with vertical sides, $0.77 \mathrm{~m}$ deep, and had a floor sloped at $0.5 \%$. The cells were filled with crushed limestone gravel to a depth of $0.4 \mathrm{~m}$, ranging in
Fig. 1 a Layout of the existing NITK treatment plant, $\mathbf{b}$ layout of the proposed pilot-scale HSSF-CW and VFCW

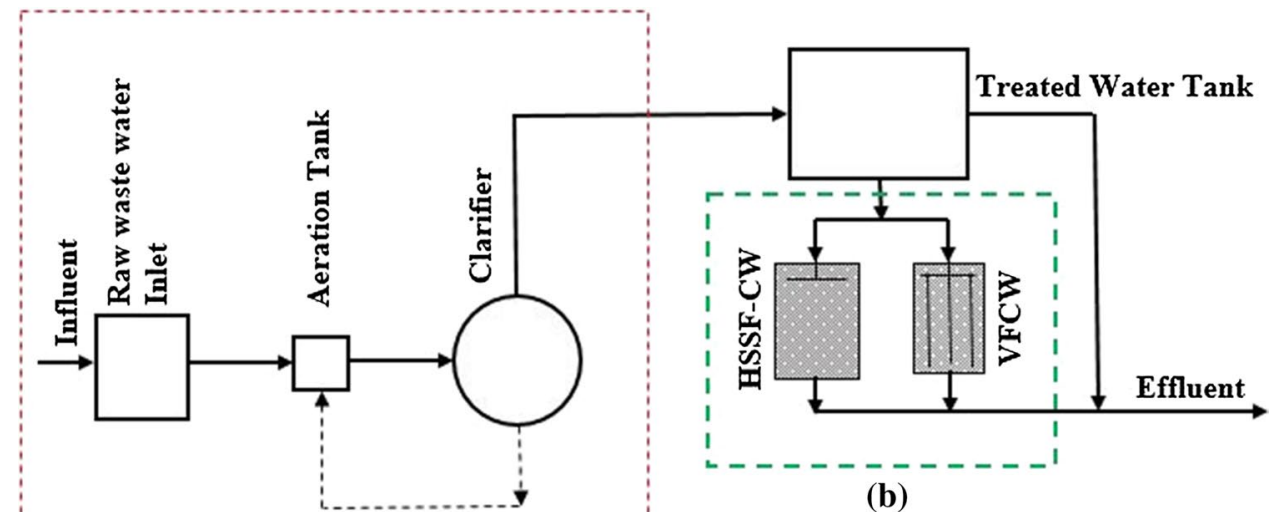

Recirculation

(a) 
size from 8 to $32 \mathrm{~mm}$, with an average porosity of $51 \%$. The wetland is operated as a batch flow reactor at two HRTs of $24 \mathrm{~h}$ and $12 \mathrm{~h}$ from the effluent of existing NITK treatment plant. The water depth was maintained at $0.4 \mathrm{~m}$ within the gravel bed and with the aid of fixed outlet pipes (collecting effluent from the floor level of the wetland cell).

The media of vegetative submerged bed systems perform many functions: (1) act as rooting material for vegetation, (2) help to evenly distribute and collect flow at the inlet and outlet, respectively, (3) provide surface area for microbial growth, (4) filter and trap particles. In short, they act as media for water flow as well as for planting the vegetation (Wallace and Knight 2006). The wetland system is divided into three zones, namely inlet zone, treatment zone and outlet zone. The large-sized gravel was placed near the inlet and outlet of the wetland for uniform distribution of the influent wastewater and drainage of the wetland, respectively (USEPA 2000). The treatment zone is again divided into two, zone 1 of $30 \%$ length with gravel grading of $16-32 \mathrm{~mm}$ and zone 2 with $6-10 \mathrm{~mm}$ (USEPA 2000). The treatment zone was maintained at an aspect ratio of 1:1 (Wallace and Knight 2006). Figure 2 represents the schematic representation of pilot-scale HSSF-CW.

\section{Design of pilot-scale VFCW}

The pilot-scale VFCW has a surface area of $0.70 \mathrm{~m}^{2}$. Here, areal-based design methods were adopted for pollutant reduction (Kadlec and Wallace 2008). The pilot-scale VFCW is designed for an influent flow of $0.25 \mathrm{~m}^{3} /$ day considering an average BOD loading of $100 \mathrm{mg} / \mathrm{l}$. The areal loading rate (ALR) is provided of $35 \mathrm{~kg} / \mathrm{ha}$ day for attaining a discharge limit of BOD less than $30 \mathrm{mg} / \mathrm{l}$ (Wallace and Knight 2006). In situ locally available media were used for the construction of the pilot-scale model.
The media from bottom consist of gravel size of $16-32 \mathrm{~mm}$ of $0.15 \mathrm{~m}$ depth, gravel size of $6-10 \mathrm{~mm}$ of $0.20 \mathrm{~m}$ depth and top layer with a $d_{10}$ between 0.25 and $1.2 \mathrm{~mm}$, a $d_{60}$ between 1 and $4 \mathrm{~mm}$, and the uniformity coefficient $\left(U=d_{60} / d_{10}\right)$ less than 3.5 of a depth $0.35 \mathrm{~m}$. A topmost layer gravel size of $16-32 \mathrm{~mm}$ was provided at a depth of $0.05 \mathrm{~m}$ in order to avoid problems during clogging and fly nuisance as shown in Fig. 3.

\section{Wetland vegetation}

Wetland plants require optimum environmental conditions in each phase of their life cycles, including germination and initial plant growth, adequate nutrition, normal seasonal growth patterns, and rates of plant senescence and decay (USEPA 2000). The pilot plants used in the vegetation were Cyperus rotundus and Pennisetum pedicellatum.

Cyperus rotundus is a small plant with its individuals reaching up to a height of $40 \mathrm{~cm}$. It is a very proliferative weed and found in several countries. It is normally found in

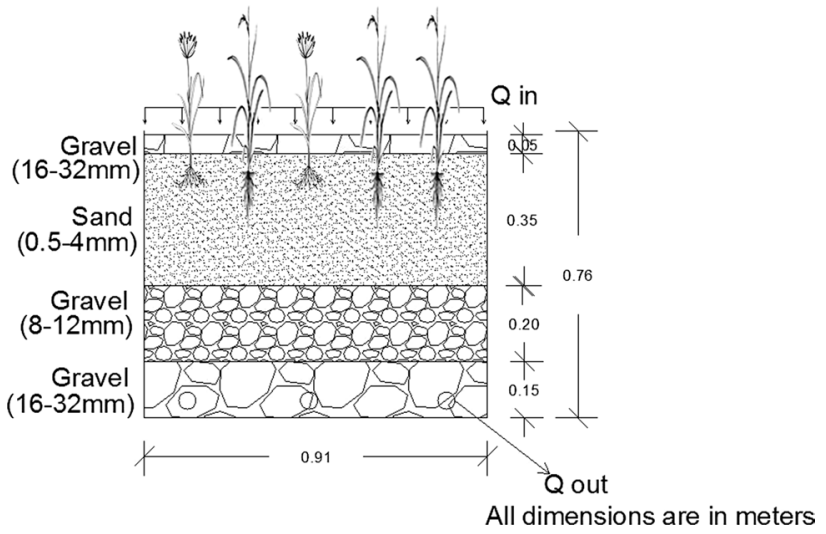

Fig. 3 Schematic representation of pilot-scale model VFCW
Fig. 2 Schematic representation of pilot-scale HSSF-CW

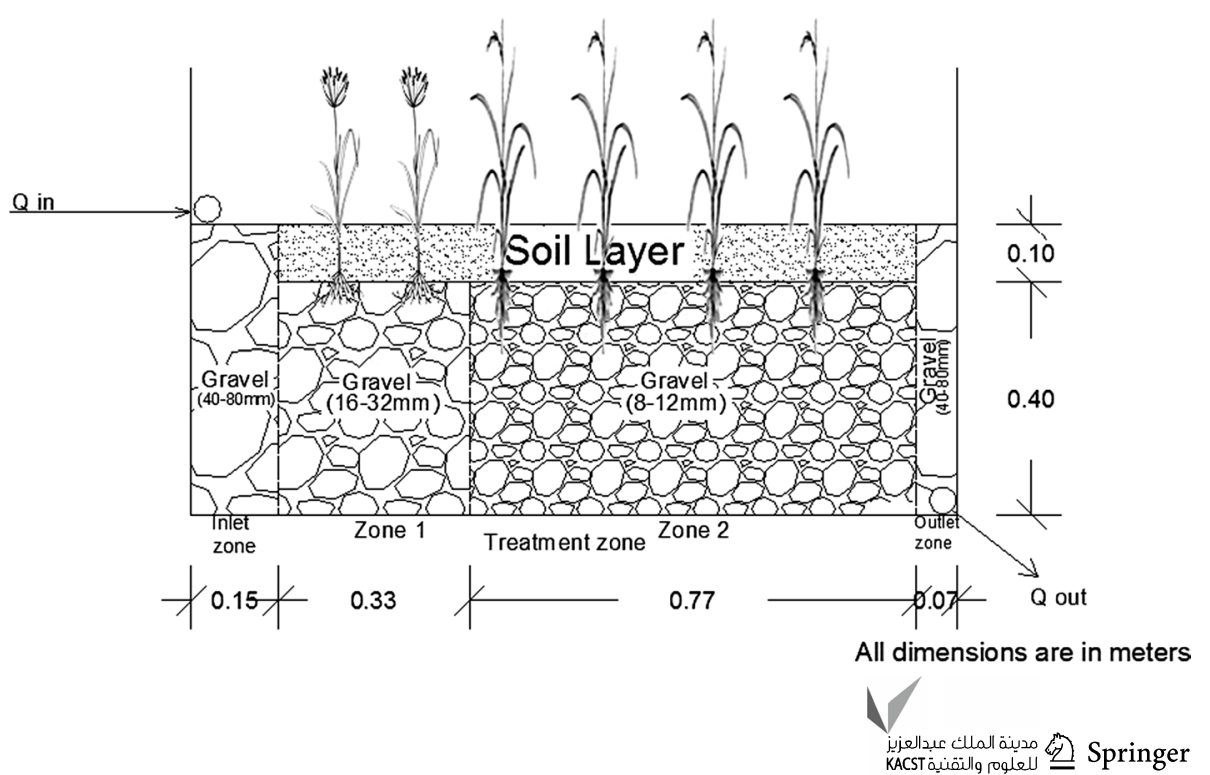


agricultural lands and garden soils locally. It is used in Ayurveda to treat fevers, digestive system disorders, etc. Plant extract is used in hair oils and for other medicinal purposes. Cyperus showed a steady increase in shoot density over the trial (Tanner 1996) on a comparison of growth and nutrient uptake.

Pennisetum pedicellatum is an aggressive grass weed, commonly invading agricultural land in the tropics, where dense infestations can force the abandonment of whole farms. It spreads quickly and is difficult to control. The plant individuals reaching an average height between 30 and $150 \mathrm{~cm}$ might show more growth rate on the influent water characteristics, commonly used as fodder locally. These plants were planted at a center-to-center spacing of $15 \mathrm{~cm}$ with 2:1 ratio between Pennisetum pedicellatum and Cyperus rotundus.

\section{Operational and analytical procedures}

The pilot-scale HSSF-CW and VFCW were monitored from February 14, 2018, to May 15, 2018. All wastewater samples were grab samples taken manually. Poor removals are attributed to the microbial breakdown of carbonaceous compounds being limited by low oxygen availability (Solano et al. 2004). The pilot-scale models HSSF-CW and VFCW were monitored for two different hydraulic retention times (HRTs) of $12 \mathrm{~h}$ and $24 \mathrm{~h}$.

The parameters measured to assess the performance of the HSSF-CW included COD, $\mathrm{BOD}_{5}$, total suspended solids (TSS), $\mathrm{NO}_{3}-\mathrm{N}, \mathrm{NH}_{4}-\mathrm{N}, \mathrm{PO}_{4}-\mathrm{P}$ and most probable number. All wastewater and treated samples were analyzed in accordance with the Standard Methods for Examination of Water and Wastewater (APHA 2012).

\section{Results and discussion}

In this study, the domestic wastewater effluent from NITK treatment plant is fed at a constant flow rate of $0.25 \mathrm{~m}^{3} /$ day to the pilot-scale HSSF-CW and VFCW systems operated in subsurface flow. The CWs were operated at 24-h and 12-h HRTs. The analysis for 12-h HRT was done after attaining the stable removal rate, from the first week of April 2018.

\section{$\mathrm{BOD}_{5}$}

Removal of BOD in vegetated submerged wetlands is supposed to be due to the aerobic microbial degradation and sedimentation processes (Choudhary et al. 2011). Soluble organic compounds are removed by the microbial growth on the media surfaces and attached to the roots and rhizomes of plants. Organic matter in wastewater contains nearly $45-50 \%$ carbon $(\mathrm{C})$, which is consumed by a wide array of microorganisms as a source of energy. The $\mathrm{BOD}_{5}$ removal efficiencies were found to be increasing during the first 3 weeks of operation of the pilot-scale plants. The influent-effluent variation of $\mathrm{BOD}_{5}$ concentration in HSSF-CW and VFCW at 24-h hydraulic retention time is shown in Fig. 4a.

The $\mathrm{BOD}_{5}$ removal efficiency was found to be stable from the fourth week of operation of the pilot model VFCW and from the fifth week in HSSF-CW. At this time, the plant growth was observed to be $18-28 \mathrm{~cm}$ for $C$. rotundus and 53-98 cm for P. Pedicellatum in VFCW and $16-23 \mathrm{~cm}$ for

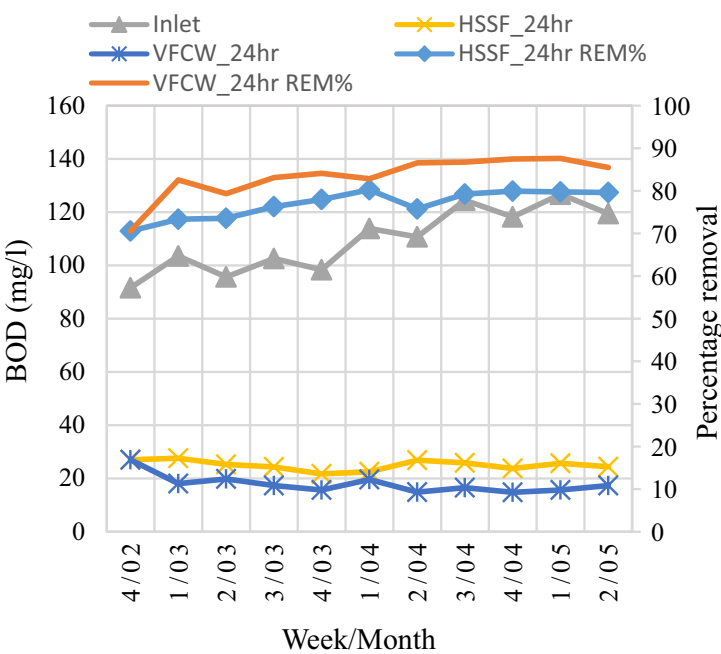

(a)

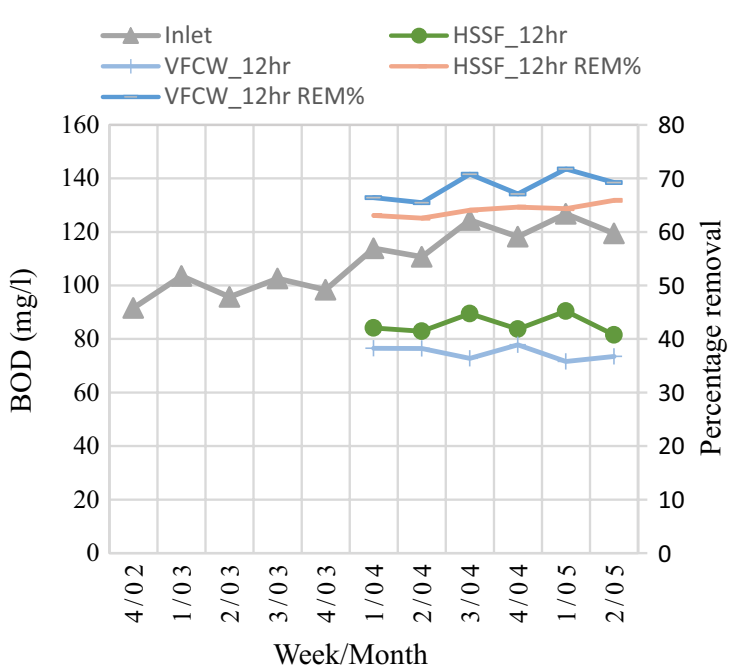

(b)

Fig. 4 a BOD5 influent, effluent concentration and percentage removal of HSSF-CW and VFCW for 24-h HRT, b BOD5 influent, effluent concentration and percentage removal of HSSF-CW and VFCW for 12-h HRT 
C. rotundus and 46-87 $\mathrm{cm}$ for P. Pedicellatum in HSSF-CW. It was found to have an average removal efficiency of $83 \%$ in $\mathrm{VFCW}$ and $77 \%$ in $\mathrm{HSSF}-\mathrm{CW}$ for 24-h retention time, as shown in Fig. 4b. In 12-h retention time, the average removal efficiencies were $68 \%$ and $64 \%$ in VFCW and HSSF-CW, respectively. The average outflow concentration in VFCW and HSSF-CW is $17.86( \pm 4.95) \mathrm{mg} / \mathrm{l}$ and $24.97( \pm 4.92)$, respectively, which is lower than the desirable standards.

\section{COD}

In the wetland systems, the presence of humic materials leads to higher $\mathrm{COD}$ values. The $\mathrm{BOD}_{5} / \mathrm{COD}$ ratio in the influent wastewater to the pilot $\mathrm{HSSF}-\mathrm{CW}$ ranged from 0.45 to 0.71 , which indicates that the wastewater is readily biodegradable. It is shown that both the horizontal flow and vertical flow systems can remove more than $90 \%$ of organic load and of total $\mathrm{N}$ and P (Luederitz et al. 2001) with multiple-stage treatment wetlands. VFCW units were quite efficient in organic matter $\left(\mathrm{BOD}_{5}\right.$ and $\left.\mathrm{COD}\right)$ with mean removal efficiencies of $78 \%$ for pilot-scale plant of $0.57 \mathrm{~m}^{2}$ (Stefanakis and Tsihrintzis 2012). The experimental analysis on the effluent from pilot-scale models was carried out and found to have an average removal efficiency of $65 \%$ in VFCW and $60 \%$ in HSSF-CW in 24-h retention time as shown in Fig. 5b. As expected, the 12-h HRT was showing lesser removal efficiency than 24-h HRT in case of COD removal due to the lesser amount of oxygen released from roots. The average removal efficiency for 12 -h HRT is $50 \%$ and $48 \%$ in VFCW and HSSF-CW, respectively. The effluent outflow of 24-h HRT pilot-scale models shows an average outflow concentration of $60.52( \pm 4.78) \mathrm{mg} / \mathrm{l}$ in VFCW and $71.33( \pm 6.75)$ in HSSF-CW, as shown in Fig. 5a.

\section{Nitrogen}

Plant species differ in their preferred forms of nitrogen absorbed, depending on the forms available in the soil (Lambers et al. 1998). The movement of nitrogen through the vegetation results in the enhancement of processes other than those in the soil, water column and the associated biofilms (Kadlec and Wallace 2008). Mainly three forms of nitrogen (ammonia nitrogen, nitrite and nitrate nitrogen) were tested during the experimental period in which nitrite levels in the influent as well as in the effluent from VFCW were very low. Treatment of domestic wastewater in vertical and horizontal subsurface flow constructed wetlands had an average removal of $72.2 \%$ for $\mathrm{NH}_{4}{ }^{+}-\mathrm{N}$ (Zurita et al. 2009). Ammonia nitrogen average removal efficiency was found to be $67.19 \%$ and $84.47 \%$ for $12-\mathrm{h}$ and $24-\mathrm{h}$ HRTs, respectively, in VFCW and $57 \%$ and $64 \%$ for $12-\mathrm{h}$ and $24-\mathrm{h}$ HRTs in HSSF-CW (Fig. 6a, b). The results show that a greater reduction of ammonia nitrogen concentration was found in VFCW than HSSF-CW for the same HRT.

Nitrate nitrogen average removal efficiency was $47.54 \%$ and $66.75 \%$ for 12-h and 24-h HRTs in VFCW and $69 \%$ and $51 \%$ in HSSF-CW. A slightly better removal efficiency is found in HSSF-CW in terms of nitrate removal during the study period. The effluent concentration for $24 \mathrm{~h}$ for VFCW is 7.493 ( \pm 2.1348$) \mathrm{mg} / \mathrm{l}$ and for HSSF-CW is 7.5570 $( \pm 1.6145) \mathrm{mg} / \mathrm{l}$ as shown in Fig. 7a and b.

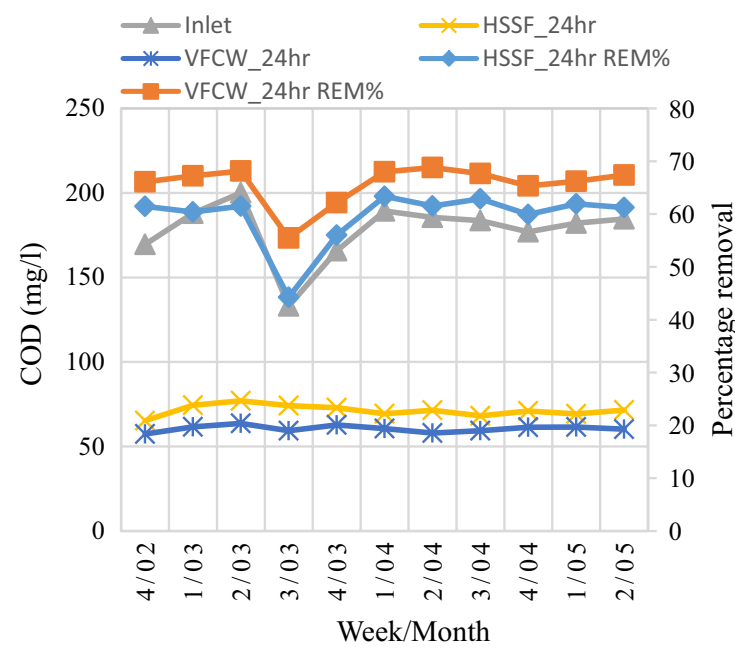

(a)

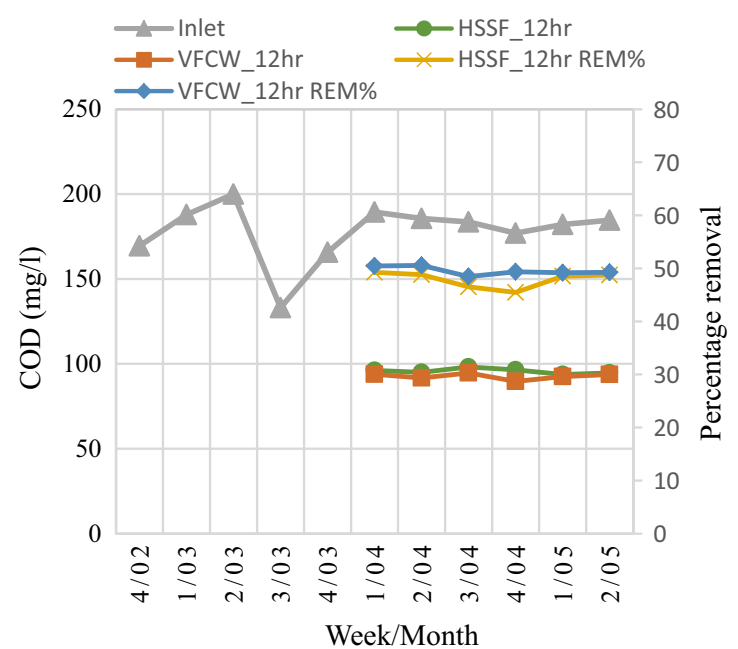

(b)

Fig. 5 a COD influent, effluent concentration and percentage removal of HSSF-CW and VFCW for 24-h HRT, b COD influent, effluent concentration and percentage removal of HSSF-CW and VFCW for 12-h HRT

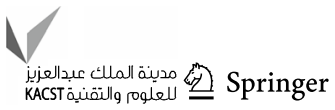




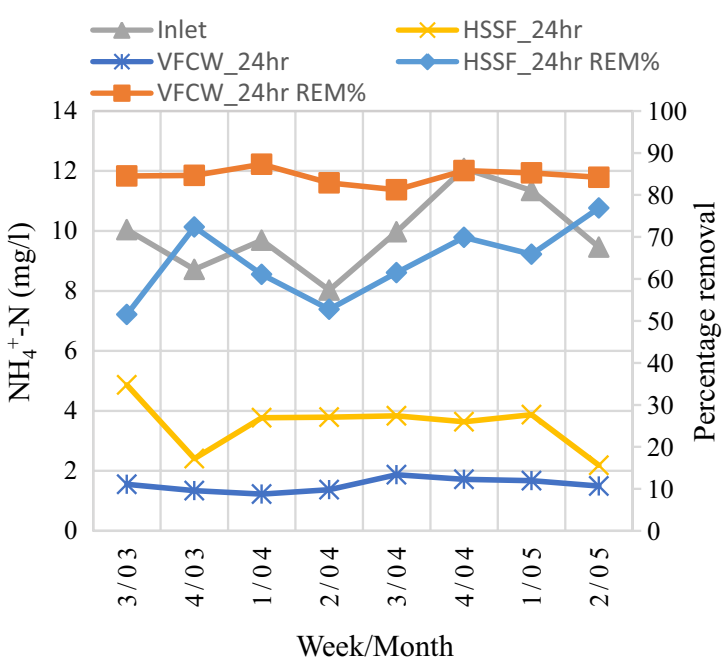

(a)

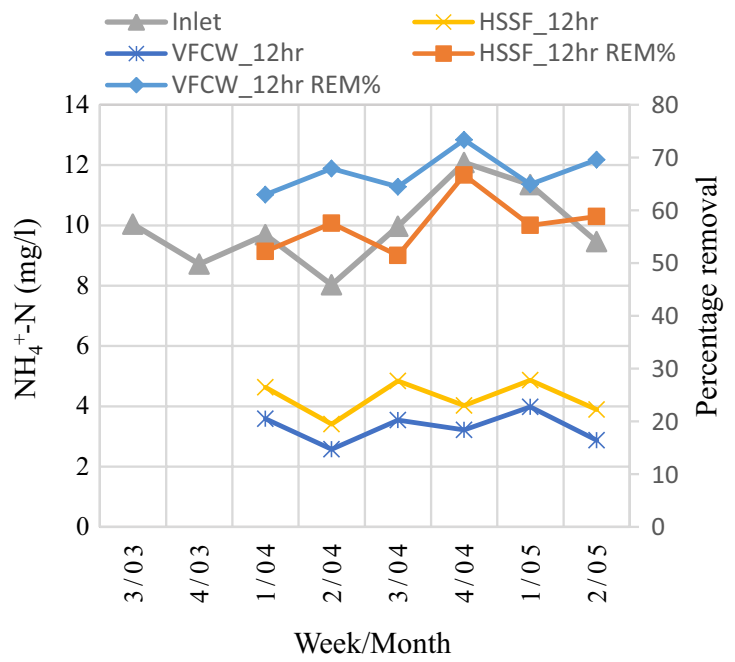

(b)

Fig. 6 a Ammonia nitrogen $(\mathrm{NH} 4+\mathrm{N})$ influent, effluent concentration and percentage removal of HSSF-CW and VFCW for 24-h HRT, b ammonia nitrogen $(\mathrm{NH} 4+-\mathrm{N})$ influent, effluent concentration and percentage removal of HSSF-CW and VFCW for 12-h HRT

\section{Phosphorus}

Phosphorus reduction in VFCW has been found in significant rate for the pilot scale and found to be high when compared to the reduction in nitrogen removal (Fig. 8). Low TP concentrations can be reduced to even lower ones, but large phosphorus load removal requires a large wetland area (Kadlec and Wallace 2008). Phosphorus can be removed directly by cattail uptake or storage in sediments (Sakadevan and Bavor 1998). Phosphorus removal is significantly influenced by physicochemical characteristics of the used substrate (Brix and Arias 2005).

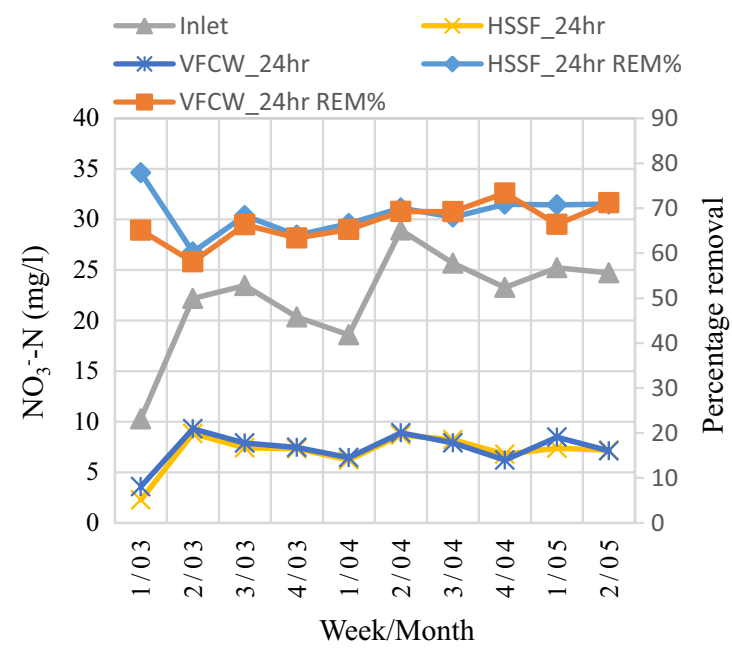

(a)
In subsurface flow wetlands, soluble phosphorus will move with the flow, whereas phosphorus linked with particulate matter will be removed by filtration and interception mechanisms present in the wetland bed (Kadlec and Wallace 2008). The phosphorous is measured as $\mathrm{PO}_{4}-\mathrm{P}$ in the laboratory, and the average mass removal efficiency is $90 \%$ and $75 \%$ for $24-\mathrm{h}$ and 12 -h HRT in VFCW and $85 \%$ and $72 \%$ in HSSF-CW as shown in Fig. 8a and b. The $\mathrm{PO}_{4}-\mathrm{P}$ concentration, shown in Fig. 8a, shows higher treatment performance than that reported in the literature (20-30\%) for VFCWs treating medium-strength domestic sewage (Wood 1995; Lantzke et al. 1999; Brix and Arias 2005).The average outlet

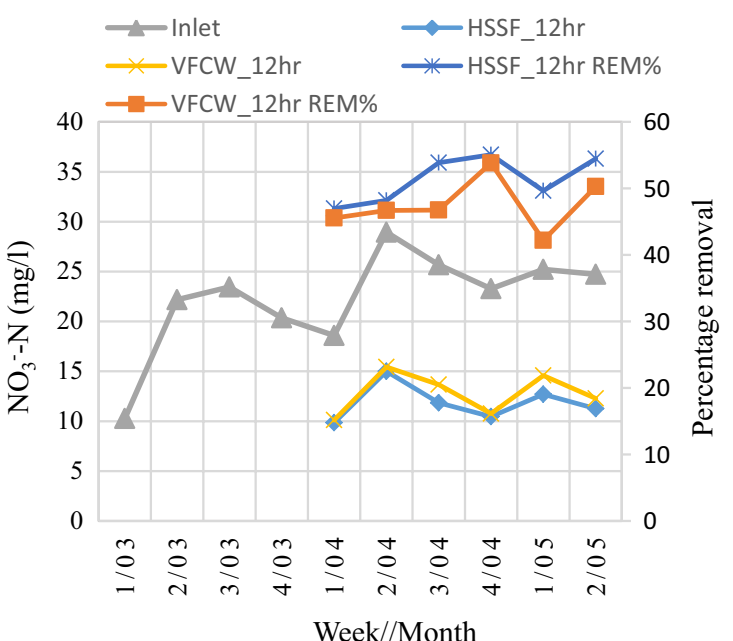

(b)

Fig. 7 a Nitrate nitrogen $\left(\mathrm{NO}_{3}-\mathrm{N}\right.$ influent, effluent concentration and percentage removal of HSSF-CW and VFCW for 24-h HRT, b nitrate nitrogen $\left(\mathrm{NO}_{3}-\mathrm{N}\right.$ influent, effluent concentration and percentage removal of HSSF-CW and VFCW for 12-h HRT 


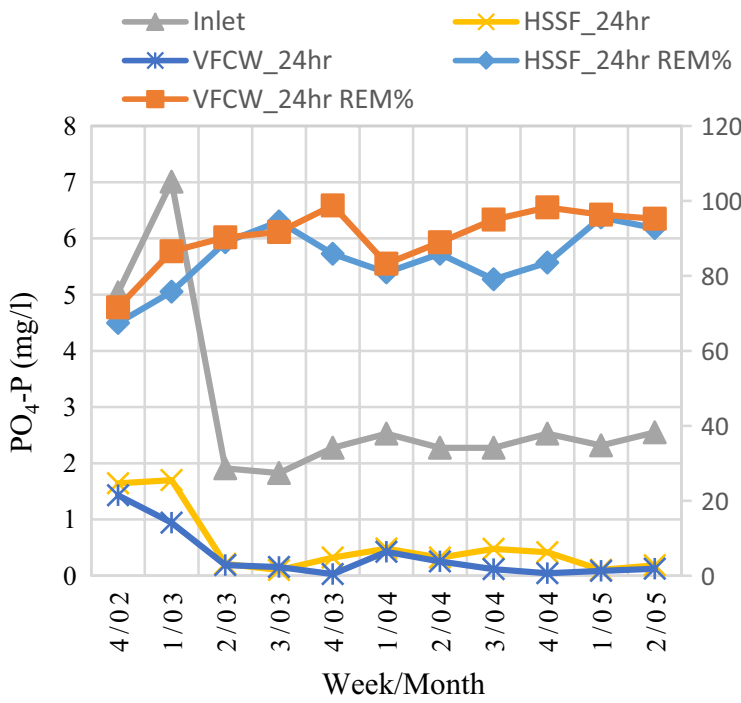

(a)

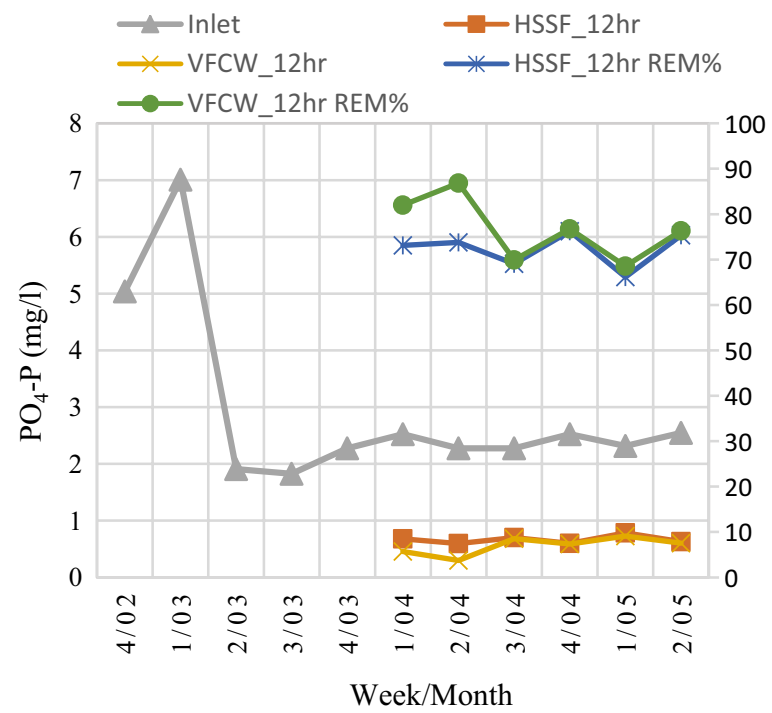

(b)

Fig. 8 a Phosphates $\left(\mathrm{PO}_{4}-\mathrm{P}\right)$ influent, effluent concentration and percentage removal of HSSF-CW and VFCW for 24-h HRT, b phosphates $\left(\mathrm{PO}_{4}-\mathrm{P}\right)$ influent, effluent concentration and percentage removal of HSSF-CW and VFCW for 12-h HRT

concentration in VFCW and HSSF-CW is $0.3429( \pm 0.1907)$ $\mathrm{mg} / \mathrm{l}$ and $0.3231( \pm 0.1204) \mathrm{mg} / \mathrm{l}$, respectively, for 24-h HRT as mentioned in Fig. 8a.

\section{TSS}

In contrast to the results obtained in the reduction of BOD and COD for 24-h pilot-scale VFCW and HSSF-CW, TSS average removal efficiency was significant and found to be 90-95\%. TSS are removed mainly by physical processes such as sedimentation and filtration (Kadlec and Wallace
2008) in accordance with aerobic or anaerobic microbial degradation inside the substrate. The uniformly graded sand and gravel substrate along with the vegetation provided better treatment efficiency for the pilot plants. The high TSS removal rates observed in this study are not different from those reported in other studies. During the whole study period, the average total suspended solid concentration in the effluent was $8.46( \pm 2.6 \mathrm{mg} / \mathrm{l})$ in HSSF-CW and 8.32 $( \pm 1.7) \mathrm{mg} / \mathrm{l}$ in VFCW.

\section{Coliform}

Pathogen treatment in wetland systems depends on mechanisms within the $\mathrm{CW}$ system including sedimentation, natural die-off, temperature, oxidation, predation, unfavorable water chemistry, adhesion to biofilm, mechanical filtration, exposure to biocides and UV radiation. Total coliforms were the first approved indicator organisms which include bacterial species that are rod-shaped, are stain gram-negative, do not form spores, are facultative anaerobic, and ferment lactose with gas production in $48 \mathrm{~h}$ at a temperature of $35^{\circ} \mathrm{C}$ (Kadlec and Wallace 2008).

The most probable number (MPN) of total coliforms per $100 \mathrm{ml}$ was calculated by doing presumptive test and was observed that the influent to the wetland system has a value of 28/100 ml of sample and the effluent to the wetland system has a value of 6.1/100 $\mathrm{ml}$ of sample in HSSF-CW and $5.5 / 100 \mathrm{ml}$ of sample in VFCW, which shows the reduction in concentration of total coliforms after the tertiary treatment. There is a significant reduction in the microbial count from the inlet to outlet of the HSSF-CW. So after providing disinfection, the water can be reused accordingly. The USEPA 2000 (Agency et al. 2004) suggests the reuse of treated water after disinfection if MPN of fecal coliform $/ 100 \mathrm{ml}$ is found to be $<200 \mathrm{FC} / 100 \mathrm{ml}$ for landscape impoundments, construction use, industrial reuse such as once-through cooling and recirculating cooling towers, environmental reuse in wetlands and marshes where groundwater should be evaluated.

\section{Wetland vegetation}

The pilot-scale model vegetation growth rate measurement during the operational phase is given in Table 2. The vegetation was cut during the end of April 2nd week and has observed significant regrowth in just 2-week duration. VFCW showed significantly higher plant growth than compared to HSSF-CW, which is in line with the variations in the removal efficiencies of various parameters for the treated wastewater. Further, while cutting the plant for an attempt to uproot one of the plants, the widespread of roots to the substrates was observed.

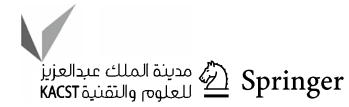


Table 2 Plant growth measurement during the operational period of pilot-scale VFCW from February 14, 2018 , to May 15, 2018 (vegetation cutting was carried out at the end of April 2nd week)

\begin{tabular}{|c|c|c|c|c|c|c|}
\hline \multirow{2}{*}{$\begin{array}{l}\text { Month } \\
\text { Week }\end{array}$} & \multirow{2}{*}{$\begin{array}{l}\text { Feb } \\
2-4\end{array}$} & \multicolumn{2}{|l|}{ March } & \multicolumn{2}{|l|}{ April } & \multirow{2}{*}{$\begin{array}{l}\text { May } \\
1-2\end{array}$} \\
\hline & & $1-2$ & $3-4$ & $\overline{1-2}$ & $3-4$ & \\
\hline \multicolumn{7}{|c|}{ Plant height $(\mathrm{cm})$} \\
\hline \multicolumn{7}{|l|}{ C. rotundus } \\
\hline HSSF-CW & $5-10$ & $10-16$ & $16-23$ & $23-38$ & $8-14$ & $14-32$ \\
\hline VFCW & $5-10$ & $10-18$ & $18-28$ & $28-42$ & $8-22$ & $22-38$ \\
\hline \multicolumn{7}{|c|}{ P. Pedicellatum } \\
\hline HSSF-CW & $15-24$ & $24-46$ & $46-87$ & $87-142$ & $15-38$ & $38-96$ \\
\hline VFCW & $15-28$ & $28-53$ & $53-98$ & $98-147$ & $15-42$ & $42-104$ \\
\hline
\end{tabular}

Table 3 Cost analysis of the pilot-scale model HSSF-CW and VFCW during the study period from February 14, 2018, to May 15, 2018

\begin{tabular}{lccr}
\hline Cost & Unit & \multicolumn{2}{c}{ US Dollar (\$) } \\
\cline { 3 - 4 } & & HSSF-CW & VFCW \\
\hline Capital cost & & & \\
HSSF tank (650 L) & 1 & 114.78 & 85.90 \\
0.5HP pump & 1 & 6.66 & 18.51 \\
Overhead water tank (250 L) & 1 & 11.11 & 11.11 \\
Pipes and fittings & & 14.81 & 14.81 \\
Labor charge & & 14.81 & 14.81 \\
$\quad$ Transportation charges & & & \\
Operational and maintenance cost & & 0.30 & 0.30 \\
Pump operation cost per KLD & & & \\
$\quad$ (electricity for 90 days) & & 2.96 & 2.96 \\
$\quad$ Miscellaneous & & 183.94 & 155.06 \\
Total & &
\end{tabular}

\section{Cost analysis}

The total cost of the pilot-scale models includes a major portion of the capital cost and a minor operational and maintenance cost. The expenditure for the entire process is mentioned in Table 3. The land cost is excluded from the expenditure since it was utilized besides the existing NITK treatment plant. The substrate cost and plant cost are excluded from the cost analysis since it was obtained from the local premises. The total expenditure for the pilot-scale models is shown in Table 3 .

\section{Conclusion}

The treatment process in the wetland is generally difficult to understand due to the complex physical, chemical and biological processes involved in it along with variations in the real-time wastewater. The major conclusions arrived during the study are summarized as follows:
- This study revealed the successful performance of the HSSF-CW and VFCW for the tertiary treatment of NITK treatment plant effluent with respect to organic matter $\left(\mathrm{BOD}_{5}\right.$ and $\left.\mathrm{COD}\right), \mathrm{TSS}$, nitrogen, phosphorous and pathogen.

- The VFCW showed better mass removal efficiency when compared with HSSF-CW.

- The total treatment process is influenced by the vegetation, sand strata and substrate interaction.

- Locally available plants used in the pilot-scale model, C. rotundus and $P$. pedicellatum, showed prominent growth and quick survival in the treatment wetland bed.

- Phosphates removal efficiency was promising and stable in the treatment process and hence can be adapted in small-scale purposes.

- Constructed wetland process being complex there should be regional-specific design and vegetation selection studies to be carried out for proper guidelines for upcoming CWs.

Thus, constructed wetland can be considered as a sustainable alternative to the tertiary conventional treatment of domestic wastewater, thus making it possible for reuse. Provided the minimal maintenance necessities, the easiness of operation and the decent removal performance of contaminants, the cost-effective constructed wetland technology can help to relieve the current wastewater management problem in developing countries.

\section{Compliance with ethical standards}

Conflict of interest The authors declare that they have no conflict of interest.

Open Access This article is distributed under the terms of the Creative Commons Attribution 4.0 International License (http://creativeco mmons.org/licenses/by/4.0/), which permits unrestricted use, distribution, and reproduction in any medium, provided you give appropriate credit to the original author(s) and the source, provide a link to the Creative Commons license, and indicate if changes were made. 


\section{References}

Agency USEP, Division MS, Transfer T et al. (2004) Guidelines for water reuse office of water

APHA (2012) Standard methods for the examination of water and wastewater, $22^{\text {nd }}$ ed

Arts ACDB (2012) Review on waste water treatment technologies

Brix H, Arias CA (2005) The use of vertical flow constructed wetlands for on-site treatment of domestic wastewater: New Danish guidelines. Ecol Eng 25:491-500. https://doi.org/10.1016/j.ecole ng.2005.07.009

Choudhary AK, Kumar S, Sharma C (2011) Constructed wetlands: an approach for wastewater treatment. Elixir Pollut 37(37):3666-3672

Kadlec RH, Wallace SD (2008) Treatment wetlands, 2nd ed. CRC Press, Boca Raton, FL, USA

Lambers H, Chapin SF, Pons TL (1998) Plant physiological ecology. Springer, Berlin

Lantzke IR, Mitchell DS, Heritage AD, Sharma KP (1999) A model of factors controlling orthophosphate removal in planted vertical flow wetlands. Ecol Eng 12:93-105. https://doi.org/10.1016/ S0925-8574(98)00056-1

Luederitz V, Eckert E, Lange-weber M et al (2001) Nutrient removal efficiency and resource economics of vertical flow and horizontal flow constructed wetlands. Ecol Eng 18:157-171

Nyquist J, Greger M (2009) A field study of constructed wetlands for preventing and treating acid mine drainage. Ecol Eng 35:630-642. https://doi.org/10.1016/j.ecoleng.2008.10.018

Prochaska CA, Zouboulis AI (2006) Removal of phosphates by pilot vertical-flow constructed wetlands using a mixture of sand and dolomite as substrate. Ecol Eng 26:293-303. https://doi. org/10.1016/j.ecoleng.2005.10.009

Prochaska CA, Zouboulis AI, Eskridge KM (2007) Performance of pilot-scale vertical-flow constructed wetlands, as affected by season, substrate, hydraulic load and frequency of application of simulated urban sewage. Ecol Eng 31:57-66. https://doi. org/10.1016/j.ecoleng.2007.05.007

Sakadevan K, Bavor HJ (1998) Phosphate adsorption characteristics of soils, slags and zeolite to be used as substrates in constructed wetland systems. Water Res 32:393-399. https://doi.org/10.1016/ s0043-1354(97)00271-6

Solano ML, Soriano P, Ciria MP (2004) Constructed wetlands as a sustainable solution for wastewater treatment in small villages.
Biosyst Eng 87:109-118. https://doi.org/10.1016/j.biosystems eng.2003.10.005

States U (2000) Manual constructed wetlands treatment of municipal wastewaters manual constructed wetlands treatment of municipal wastewaters

Stefanakis AI, Tsihrintzis VA (2012) Effects of loading, resting period, temperature, porous media, vegetation and aeration on performance of pilot-scale vertical flow constructed wetlands. Chem Eng J 181-182:416-430. https://doi.org/10.1016/j.cej.2011.11.108

Tanner CC (1996) Plants for constructed wetland treatment systemsa comparison of the growth and nutrient uptake of eight emergent species. Ecol Eng 7:59-83. https://doi.org/10.1016/09258574(95)00066-6

USEPA (2000) Wastewater technology fact sheet wetlands: subsurface flow. Environ Prot Agency pp 1-7. doi: EPA 832-F-99-062

Vymazal J (2014) Constructed wetlands for treatment of industrial wastewaters: a review. Ecol Eng 73:724-751. https://doi. org/10.1016/j.ecoleng.2014.09.034

Wallace S, Knight R (2006) Small-scale constructed wetland treatment systems. IWA Publishing, London

Wood A (1995) Constructed wetlands in water pollution control: fundamentals to their understanding. Water Sci Technol 32:21-29

Wu T, Sansalone J (2013) Phosphorus equilibrium. II: Comparing filter media, models, and leaching. J Environ Eng 11:1152-1161. https ://doi.org/10.1061/(ASCE)EE.1943-7870

Yalcuk A, Ugurlu A (2009) Comparison of horizontal and vertical constructed wetland systems for landfill leachate treatment. Bioresour Technol 100:2521-2526. https://doi.org/10.1016/j. biortech.2008.11.029

Zhao YJ, Liu B, Zhang WG et al (2010) Performance of pilot-scale vertical-flow constructed wetlands in responding to variation in influent $\mathrm{C} / \mathrm{N}$ ratios of simulated urban sewage. Bioresour Technol 101:1693-1700. https://doi.org/10.1016/j.biortech.2009.10.002

Zurita F, De Anda J, Belmont MA (2009) Treatment of domestic wastewater and production of commercial flowers in vertical and horizontal subsurface-flow constructed wetlands. Ecol Eng 35:861-869. https://doi.org/10.1016/j.ecoleng.2008.12.026

Publisher's Note Springer Nature remains neutral with regard to jurisdictional claims in published maps and institutional affiliations. 